\title{
Effect of Financial Reporting Quality on Financial Performance of Manufacturing Firms in Nigeria
}

\author{
Amah Kalu Ogbonnaya Amauwa Basil .C \\ Accounting Department, College of Management Sciences, Michael Okpara University of Agriculture, \\ Umudike, Abia State Nigeria
}

\begin{abstract}
.
The major purpose of the study is to examine the effect of FRQ on financial performance of Manufacturing Firms in Nigeria. The study covered the period of 2005-2014. The Impact of DPS, NAVPS, CAR, MPS, PER, and EPS were tested on FRO. Simple regression analysis was employed in testing the date collected from annual published financial statement of selected manufacturing companies. Financial reporting quality was proxy by accrual using is Dechow 1994 model. The regression result shows that DPS, CAR, MPS, PER have negative significant relationship with FRQ while NAVP and EPS has positive significant relationship with FRQ. The researcher recommended that the government should by way of regulatory authorities compel manufacturing organisations' to embark on proper recode keeping and should also see quality reporting as investment to their advantage.

Keywords: Financial reporting quality, Manufacturing Companies, Net asset value per share, Dividend per share, Current asset Market price per share, Price Earnings ratio, Earning per share.
\end{abstract}

DOI: $10.7176 / \mathrm{RJFA} / 10-11-01$

Publication date: June $30^{\text {th }} 2019$

\section{INTRODUCTION}

Financial reporting is one of the most important products of accounting system that tries to provide necessary information for users to make economic decisions on the evaluation of an economic enterprise's profitability and performance, measuring and providing information that makes it possible to evaluate the past performance and effectively assess the product, and possible future profitability and anticipated activities that can be prerequisite for achieving this goal (Bolo 2007). Financial reports are formal records of business financial activities. They provide an overview of a business profitability and financial condition in both short and long term. According to Smith (1995) accounting provide qualitative information, primarily financial in nature, about economic entity that is intended to be useful in making economic decisions, that is, in making reasonable choices among alternative courses of action. These decisions include investment decisions such as decision on whether to buy, hold in sell investment and credit decision like whether to lend or not to as well as terms of lending. Both investor and creditors do a thorough analysis of the financial statement before investment to be sure of returns or profit. Financial statements also provide reliable information to assist in decision making. The statement should contain relevant, reliable, comparable and understandable information (Kamaruzaman Mazlita and Maisarah 2009). Reliability has to do with the quality of financial information which is reasonably free from error and bias and faithfully represents what it is intended to stand for.

The quality of financial reporting is to promote transparency and deliver high quality annual report through comprehensive disclosure. The quality of financial reporting has always been an issue of interest among regulatory bodies, shareholders, researchers and the accounting profession itself. This is due to the fact that financial reporting has been a principal means of communicating financial information to outside users (Johnson, Khurana and Reynolds 2002).

When financial report is of good quality, sourcing and attracting fund both locally and international become easy and possible. It would also assist to predict the performance of the business entity, during this period of economy rescission that the Nigeria manufacturing firms are currently facing because the manufacturing sector remains a sensitive part in Nigeria economy. It is the sector that simulates the Gross Domestic Product (GP) of the country as the result of its various productive activities which involve, among many other contributions, such as export of products to boost foreign reserve, job creation for young graduates.

According to Ojeha, Mukoro and Kany (2015) in the face of the death of investment in the manufacturing sector and most especially, from the banking sector, there is need to focus strongly on how the manufacturing sector can begin to generate profit on its assets that will simulate the growths of the sector. Therefore one of the best ways to do this is to work critically at the reporting quality of this sector especially the selected firms. This is to ensure that stakeholders (i.e the providers of funds) have unlimited access to every detail in the financial report and able to understand all the facts behind the figures that have been produced.

\section{OBJECTIVE OF THE STUDY}

The main objective of this research is to investigate the effect of financial reporting quality on financial performance of manufacturing firm in Nigeria. 
(1) To assess the extent to which Financial Reporting quality affects, Earnings per Share.

(2) To determine Financial Reporting quality affect on Dividend per Share.

(3) To evaluate the extent to which Reporting quality of financial state can boost Market Price per Share.

(4) To assess the gross impact of FRQ on Price Earnings Ratio.

(5) To determine the effect of FRQ in the Net Asset value per Shares.

(6) To investigate the effect of FRQ in Current Asset Ratio.

\section{RESEARCH QUESTIONS}

To achieve the above objective the following research questions have been raised.

(1) To what extent does financial reporting quality affect performance using earning per share?

(2) To what extent does financial reporting quality help to boost the dividend price per share?

(3) To what extent has financial reporting quality affect market price per share?

(4) To what extent has financial reporting quality affect net asset value per share?

(5) To what extent has financial reporting quality affected net asset value per share?

(6) To what extent has financial reporting quality affected current asset Ratio.

\section{RESEARCH HYPOTHESES}

$\mathrm{HO}_{1} \quad$ There is no significant relationship between FRQ and Earning's per share.

$\mathrm{HO}_{2} \quad$ No significant relationship exists between the FRQ Dividend per share.

$\mathrm{H}_{3} \quad$ No significant relationship between FRQ and Market Price per share.

$\mathrm{H}_{4} \quad$ There is no significant relationship between FRQ and Price earring Ratio.

$\mathrm{H}_{5} \quad$ There is no relationship between FRQ and Net asset value per share.

$\mathrm{H}_{6} \quad$ No relationship exist between current asset Ratio and FRQ.

\section{REVIEW OF RELATED LITERATURE}

\subsection{THEORETIC FRAME WORK}

The following theories based on an

\subsubsection{Agency Theory}

Agency theory is one of the most widely used theories in management Arthus and Busentiz, (2003); Daily, Dalton and Rajagopalon (2003).

Agency theory is about the relationship between two parties, the principal (owner) and the agent (manager) Esienhardt, (1989); Jensen and Meckling( 1976). It examines this relationship from a behavioral and a structural perspective. Theory suggests that given the chance, agents will behave in a self-interested manner, behavior that may conflict with the principal's interest. As such principals will enact structural mechanisms that monitor the agent in order to club the opportunistic behavior and better align the parties' interests. Firm performance by way of lost immunization and greater efficiencies is the desired outcome of the agency theory perspective. When the ownership and management of a firm are separated, theory suggests that agency problem are created and agency cost are incurred to alleviate these problems. Separate of ownership and management is a key component of agency theory, the principal authorizes or delegates work to the agent and the agent is expected to act in the best interest of the principal.

\subsubsection{STEWARDSHIP THEORY}

Stewardship theory is also about the employment relationship between two parties, the principal (owner) and the steward (manager) (Davis et al 1997; Donaldism and Davis 1991). It to examine this relationship firms a behavioral and a structural perspective. Theory suggests that stewards will behave in a pro-social manner, behavior which is aimed at the interest of the principal and thus the organization.

Firm performance such as sales growth or profitability is the desired outcome of a stewardship perspective. Theory suggests this outcome is achieved when both the principal and the manager in the employment relationship select to behave as stewards. At the heat of stewardship theory is the assumption that the principal-steward relationship is based on a choice. When both parties choose to behave on stewards and place of the principals interest, first the theory suggests a positive impact us performance because both parties are working toward the same goal

\subsection{EMPIRICAL LITERATURE}

Empirical evidence are bound on financial reporting quality, Hassan Usman S, and Bello Anmad (2013) examined firm characteristics and financial reporting quality of listed manufacturing firms in Nigeria. They investigated firm's characteristics from the perceptive of structure, monitoring and performance element and the quality of financial reporting measured by modified model of Decheward Dechew (2002) of listed manufacturing firms in Nigeria. The work pointed out those firm characteristics of listed manufacturing firms in Nigeria has significant impact on financial reporting quality. 
Lopes Claudia Maria Ferreira P. and Cerqueira Antonio and Elisio Brandao (2011) investigated the financial reporting quality effect on European firm performance. The paper analyze whether accounting quality produces any impact on firm performance using any accounting data; the abnormal accruals methodology to evaluates accounting qualifying and ROA to determine firm performance, the study was done for 17 European countries.

Findings confirm that decreasing accounting quality will increase ROA and vice versa.

Seyed Moosa Mohammadi (2014) carried out as a study on the Relationship between financial reporting quality and investment efficiency in Tehran stock exchange. A sample of 93 firms in Tehran stock exchange was taken from 2009-2012, result showed that financial reporting quality had a significant positive correlation with the investment efficiency.

Mahwood Macinad, Froogh Heirani and Ahmed Mirhosseini (2012) examined the Relationship between Financial Reporting Quality and return volatility and the role of institutional and accounting factors. Tehran stock exchange was used with a sample 70 listed firms from 2006-2010, firms were selected according to the systematic sampling and tested by regression analysis. The findings revealed that there is no significant relationship between financial reporting quality and the return volatility.

Try Tuuisandi and Erita Puspitasari (2015) studies Financial Reporting Quality- before and after IFRS adoption using NICE Qualitative characteristics measurement. The research used paired sample test to analyze the data. While the financial reporting quality before the IFRS adoption was represented from 2009-2010, while financial reporting quality after IFRS is represented by the period 2012-2013. It was find out that IFRS adoption increase the quality of financial reporting quality.

Abdulkadir Madawlli and Noor Afea Amran (2013) studied Audit committees- how they affect financial reporting quality in Nigeria companies. A sample of 70 companies in the Nigeria stock Exchange was used, while Dechew and Dicuer (2012) model was used to measure earning's as a proxy for financial reporting quality. The result shows that an audit committee was positively associated with improved financial reporting quality.

Moses Buuenya (2014) Examine the quality of accounting information and financial performances of Uganda's public sector. The study adopted a broad of cross sectional descriptive research designs and statistical random sampling. The result shows that $58 \%$ of the financial performance level attributed to financial information quality. It is therefore desirable that public sector entities empty highly shield professionals that adhere to reporting requirements of the legal and regularly framework.

Nasrine Klai and Abdelwahed Omiri (2001) did a work on corporate Governance and Financial Reporting Quality- The case of Tunisian firms, a sample of Tunisian firms were used for the period of 1997-2007. The result reveals that governance mechanisms affect the financial information quality of the Tunisians companies.

Shehu Usman Hassan (2013) carried out a study on Financial Reporting Quality, does monitoring characteristics matter? An Empirical Analysis of Nigeria Manufacturing Sector. The study used 32 firms, using modified Dechow and Dichor's (2002 involved for reporting quality).

The result shows a significant positive relationship between monitoring characteristic and financial reporting quality.

\subsection{RESEARCH METHODOLOGY}

The study covers the Federal Republic of Nigeria. The study focuses on the effect of financial accounting reporting quality on performance of manufacturing firms in Nigeria.

\subsection{RESEARCH DESIGN}

The research design for this study is ex-post facto. The ex-post facto research design is a method of finding out possible antecedents of event that have happened but cannot be manipulated by the investigator. This design allows the researcher to describe observed events using the data derived from observation to determine the relationship between financial accounting reporting quality and firm performance.

Ani (2010), Madugba, Ekwe and Kalu (2015) Eke \& Madugba (2015) adopted the ex-post facto research design in their studies of this nature. The data for the studying is sourced from the annual financial report published by the sampled companies. The dependent variable financial performance is measured by earnings per share, dividend per share, market price per share, price earnings Ratio, net asset value per and current asset Ratio. The independent variable financial reporting quality is measured by Accrual model.

\subsubsection{DESCRIPTION OF RESEARCH VARIABLE}

The research variables we structured into dependent and independent variables for the purpose of the analysis, though the main concern is to evaluate the nature, magnitudes and strengths of their interaction between the variables. The independent variables of the study are Earnings Per Share(EPS), Dividend Per Share(DPS), Market Price per Share(MPS), Price Earnings Ratio (P/Ratio) ,Net Asset Value Per Share(NAVPS), Current Asset Ratio(CAR). While the Accruals, Model is use for financial Reporting quality which is the dependent variable. 6.2.3 EARNINGS PER SHARE (EPS).

When a firm shows convincing signs that it has the capacity and potentials of earnings especially in the capacity 
and potentials of earnings especially in the long term, investment are most likely to an increase in the earnings per share. Earnings per share are calculated by dividing the company's total earnings or income by the number of shares the company has outstanding. Total earnings are proxies in this paper by Profit before interest and tax (PBIT).

6.2.4. DIVIDEND PER SHARE (DPS).

Dividend per share is the sum of declared dividends for every ordinary issued divided by the total dividend paid to equity shareholders over an accounting year.

\subsubsection{MARKET SHARE PRICE (MPS)}

Market share price is the value of a firm's equity share. Equity share is the unit of ownership of a company. The shares are sold to generate fund for expansion, diversification and investment.

\subsubsection{NET ASSET VALUE PER SHARE (NAVPS)}

Net asset value per share is the value of a firm's total assets (fixed and current assets). Less the value of its liabilities (long and short term liabilities) divided by the number of outstanding equity share. It is an acceptable yardstick for estimating the performance of companies with respect to the property and investment of the companies.

\subsubsection{CURRENT ASSET RATIO (CAR)}

The current ratio is an indication of a firm's mallet liquidity and ability to meet creditor's demands. Acceptable current ratio vary from industry to industry and are generally between 1.5 and 3 for healthy business if a company's current ratio is in the large, then it generally indicates good shut term financial strength. If the concept liabilities exceed current assets (the current ratio is below 1) then the company may have problems meeting its shut term obligations.

\subsubsection{ACCRUALS}

Accruals are cash flow operation from its reported earnings; part of it follows inherently from the growth of business activities.

In the paper it is computed as follows

Accruals $=$ (Accounts Receivable + Inventory + other Current Assets)

(Accounts Payable+ other Current Liabilities)- Depreciation.

Why using Accounts is to construct an earnings measure that is less noisy overtime than the realized cash flow is (Dechow 1994).

\subsubsection{MODEL SPECIFICATION}

$\mathrm{FRQ}=\mathrm{f}(\mathrm{EPS}, \mathrm{DPS}, \mathrm{MPS}, \mathrm{PER}, \mathrm{NAVPS}, \mathrm{CAR})$

Where

FRQ = Financial Reporting Quality (Accrual)

EPS = Earning's Per Share

DPS $=$ Dividend per Share

MPs $=$ Market Price per Share

$\mathrm{PER}=\quad$ Price Earnings Ratio

NAVP $=$ Net Asset Value per Share

$\mathrm{CAR}=$ Current Asset Ratio.

\section{MATHEMATICAL SPECIFICATION}

$\therefore \mathrm{Y} 1=\mathrm{a}_{0}+\mathrm{a}_{1} \mathrm{X}_{1}+\mathrm{a}_{2} \mathrm{X}_{2}+\mathrm{a}_{3} \mathrm{X}_{3}+\mathrm{a}_{4} \mathrm{X}_{4}+\mathrm{a}_{5} \mathrm{X}_{5}+\mathrm{a}_{6} \mathrm{X}_{6}$

Where $\mathrm{Y} 1=$ Financial reporting quality

$\mathrm{Xi}=$ Earnings per Share

$\mathrm{X} 2=$ Dividend per Share

X3 = Market Price per Share

$\mathrm{X} 4=$ Price Earnings Ratio

X5 $=$ Net Asset Value per Share

X6 $=$ Current Asset Ratio

$\mathrm{a}_{0}=$ the parameter which represent the intercept. 


\subsection{Results and Discussion \\ REGRESSION \\ (Data Set) \\ Variables Entered/Removed ${ }^{\text {a }}$

\begin{tabular}{|l|l|l|l|}
\hline Model & Variables Entered & Variables Removed & Method \\
\hline 1 & per, dps, car, navps, eps & & Enter \\
\hline
\end{tabular}

a. Dependent Variable: accruals

b. All requested variables entered

Model Summary

\begin{tabular}{|l|l|r|r|r|}
\hline Model & R & R Square & Adjusted R Square & Std. Error of the Estimate \\
\hline 1 & $.645^{\mathrm{a}}$ & .416 & .334 & .47533 \\
\hline
\end{tabular}

a. Predictors: (Constant) per, dps,car, mps, navps, eps

\section{ANOVA ${ }^{a}$}

\begin{tabular}{|l|r|r|r|l|l|}
\hline Model & Sum of squares & df & Mean Square & F & Sig. \\
\hline $1 \quad$ Regression & 6.907 & 6 & 1.151 & 5.095 & $.000^{\mathrm{b}}$ \\
Residual & 9.715 & 43 & .226 & & \\
Total & 16.622 & 49 & & & \\
\hline
\end{tabular}

a. Dependent Variable: accruals

b. Predictors: (Constant), per, dps, car, mps, navps, eps

Coefficients $^{\mathrm{a}}$

\begin{tabular}{|c|c|c|c|c|c|}
\hline \multirow[t]{2}{*}{ Model } & \multicolumn{2}{|c|}{ Unstandarlized Coefficients } & \multirow{2}{*}{$\begin{array}{l}\text { Standardized } \\
\text { Coefficients } \\
\text { Beta }\end{array}$} & \multirow[b]{2}{*}{$\mathrm{t}$} & \multirow[b]{2}{*}{ Sig. } \\
\hline & $\mathrm{B}$ & Std. Error & & & \\
\hline $\begin{array}{ll}1 & \text { (Constant) } \\
\text { eps } \\
\text { dps } \\
\text { navps } \\
\text { car } \\
\text { mps } \\
\text { per }\end{array}$ & $\begin{array}{r}7.422 \\
-.274 \\
-.190 \\
.241 \\
.328 \\
.080 \\
-.576\end{array}$ & $\begin{array}{l}.520 \\
.135 \\
.125 \\
.119 \\
.239 \\
.141 \\
.228\end{array}$ & $\begin{array}{r}-.439 \\
-.276 \\
.360 \\
.183 \\
.076 \\
-.335\end{array}$ & $\begin{array}{r}14.276 \\
-2.034 \\
-1.524 \\
2.030 \\
1.370 \\
.572 \\
-2.529\end{array}$ & $\begin{array}{l}.000 \\
.048 \\
.135 \\
.049 \\
.178 \\
.570 \\
.015\end{array}$ \\
\hline
\end{tabular}

a. Dependent Variable: accruals

$\begin{array}{llcrr}\text { Variable } & \text { Co-efficient } & \text { Standardized co-efficient beta } & \text { t-value } & \text { sig } \\ \text { Constant } & 7.442 & & 14.276 & .000 \\ \text { esp. } & -.274 & -.439 & -2.034 & .048 \\ \text { dps } & -.190 & -.276 & -1.524 & .135 \\ \text { navps } & .241 & .360 & 2.030 & .049 \\ \text { car } & .328 & .183 & 1.370 & .178 \\ \text { mps } & .080 & .076 & .572 & .570 \\ \text { per } & -.576 & -.335 & -2.529 & .015 \\ \text { R } & .645 & & & \\ \text { R-square } & .416 & & & \\ \text { Adjusted R square } & .334 & & & \\ \text { F-statistic } & 5.095 & & & \end{array}$

(a) Dependent variable : Accruals(FRQ)

(b) Predictor (content) Price earnings ratio, market price per share, net asset value per share, dividend per share, earnings per share and current assert ratio.

\subsection{DISCUSSION OF RESULTS.}

From the table above, there is significant and negative relationship between Earnings per share and Fincial reporting quality of companies in our study. This is evidenced by the co-efficient of regression value of -.274 , implying that financial reporting quality affects the EPS of the companies in our study.

Dividend per Share (DPS) is shown to be insignificant and negative as evidence by a co-efficient of regression 
value of -.190. This implies that the fincial reporting quality of companies in our study do no effect their dividend per share.

Following the result in the table above, net asset value per share is shown to have significant and positive relationship with financial reporting quality of the companies in our study. This is evidenced by co-efficient of regression value of .241 , indicating that any variable that affects net asset value per share negatively will also affect financial reporting quality of the companies in our study negatively.

Current asset ratio showed an insignificant and positive relationship with financial reporting quality of companies in our study. This is supported by a co-efficient of regression value of .328, indicating financial reporting quality does not affect current asset ration of the companies in our study.

Market value per share is shown to have an insignificant and positive relationship with financial reporting quality of the companies in our study. This is evidence by a co-efficient of regression value of .080.

The table above showed that price earnings ratio has significant and negative relationship with financial reporting quality of the companies in our study. This is evidence by a co-efficient of regression value of -.576.The adjusted of multiply determination that about $33.4 \%$ of the total variation observed in the dependent variable is explained by the predictor variables (independent) in our study. Furthermore, the F-ratio of 5.095 showed that the model is statically significant. Hence, we reject the null hypothesis and conclude that financial reporting quality affect financial performance of the companies in our study.

\section{Conclusion and Recommendations.}

In this study, effort has been made to analyze the effect of financial reporting quality on Financial Performance of Manufacturing firms in Nigeria. The study considered accounting and market based indices. Earnings per share, Market price per share, Price earnings ratio, Net asset value per share and Current asset ratio in determining the impact on FRQ on financial performance. The result of the sample for the hypothesis shows that Dividend per Share, Current asset Ratio. Price Earnings Ratio, Market price per Share has negative significant relationship with Financial reporting Quality. This result does not invalidate that this indices are not performance indices but implies that investors do not pay attention to them using them for indicators, Net asset value per Share and Earnings per Share have positive significant impact on financial reporting quality indicating that investors make use of them.

\section{1 Recommendations.}

Based on the findings of the study we make the following recommendations.

1. The government should endure more disclosures are made which will guide investors whether to invest or not.

2. Financial quality helps a company reputation by creating a positive image in the mind of investors, customers hence it should be taken seriously and be prt of financial institutions and organisations.

3. Manufacturing companies should consider financial reporting quality s an investment thus making sure that their financial statement should be of good quality.

4. Research studies should be encourage in the field of financial reporting quality as this will help investors also create awareness of what is involved in the financial statements.

\section{REFERENCES}

Abdulkadir, M. \&Noor, A.,A.(2013) Audit committee: How they affect Financial Reporting In Nigeria Companies. Journal of Modern Accounting and Auditing. Vol. 9, no8.

Ani,W.U. (2010). Ownership structure of Banks and operating performance in an Emerging Economy, Unpublished PhD Thesis. University of Nigeria Enugu campus.

Bello, A.(2009). Financial Information Quality and Inflation Accounting Disclosure in Nigerian Cement industry. Unpublished Ph.D dissertation submitted to post Graduate School of Ahmdu Bello University, Zaria.

Clandia, M.,F.P.L, Antonio, C. \& Elisio, B.(2011). The Financial reporting quality effect on European Firm performance FeP Working Paper.

Eke, O.A.and Madugba, J.U. (2015). Impact of Social and Environmental Accounting on Corporate Performance. A study of PZ CUSSONS PLC. Journal of Research and Management Science. JORMASS Vol. 1 45-52.

Kamaruzaman, A.J.,Mazhfa,M.D. \& Maisarh, A.A.(2009). The Association between firm Characteristics and Financial Statement Transparency: the Case of Egypt International Journal of Accounting vol18 no2, 211223.

Madugba, J.U.;Ekwe, M.C.\& Kalu, J.M. (2015) Corporate Tax and Revenue Generation: Evidence from Nigeria. Journal of Emerging Trends in Economies and Management Science(JETEMIS) vol6 no5 333-339.

Mahmod,M. Froogh, H. \&Ahmad, M(2012). The Relationship between Financial Reporting Quality and Return Volatility and role of intuitional and Accounting Factor. Interdisciplinary Journal of Contemporary Research in Business vol.4 no6. 
Moses, B. Quality (2012) of Accounting information and Financial Performance of Uganda's Public Sector. American Journal of Research Communication 2(5).

Nesrine, K. \& Abdelwahed, O. (2011). Corporate Governance and Fincial Reporting Quality, The case of Tunisian Firms. International Business Research vol4 no 1.

Ojeka,S.A;Mukoro, D.O \& Kanu, C. Financial Reporting Disclosure Enhance Firm Financial Performance in Nigeria Manufacturing Companies. Mediterranean Journal of Social sciences .

Seyed, M. M. (2014). The Relationship between Fincial reporting quality and investment efficiency in Tehran Stock Exchange, International Journal of Academic Research in Business and Social Sciences vol4 no6.

Shehu, U.H.\&Ahmd, B.(2013). Firm Characteristics and Financial Reporting quality of listed manufacturing Firms in Nigeria. International Journal of Accounting, Banking \&Management, vol.1 no6. 47-63.

Shehu,U. H. (2013) Financial Reporting quality, does Monitoring Characterises Matter?. An Empirical Analysis of Nigeria Manufacturing ring Sector, the Business \& Management Review. Vol3no2.

Smith, M. (1996) Qualitative Characteristics in Accounting Disclose: A derivable Trade off management Auditing Journal vol13.

Try,Y. \& Erit P.(2015) Fincial Reporting Before and After IFRS Adoption using NICE qualitie Characterises Measurement. Proscenia Social and Behavioural Science. 